\title{
SPACE CREATING STRATEGIES OF ALTERNATIVE COMMUNITIES: A COMPARATIVE STUDY OF DROP CITY AND SIEBEN LINDEN ECOVILLAGE
}

\author{
Didem BEDÜK TUNCEL \\ Mimar Sinan Fine Arts University, Turkey \\ dbeduk@gmail.com \\ https://orcid.org/0000-0001-5202-2736 \\ Armağan Seçil MELIKKOĞLU EKE \\ İstanbul Kültür University, Turkey \\ armagansecil@yahoo.com \\ https://orcid.org/0000-0002-7185-8480
}

\begin{abstract}
According to the United Nations (UN) statistics, more then 55\% of the population on earth live in urban areas. These urban areas are one of the main reasons for increasing global warming and climate crisis. The danger of this crisis will be reduced by increasing the contribution of units forming sustainable living spaces and common alternative living spaces. In this research, it is aimed to determine the strategies of man's creation of space by querying through the created alternative living spaces. These strategies, which constitute the essence and originality of the work, are handled within a framework that extends from the thinking and lifestyle of the community to the possibilities of the environment in which the living space is located. In the scope of the study, one of the first alternative communities of the 60 's that is Drop City and an ongoing eco-village of the 90's that is Sieben Linden Ecovillage samples were investigated through the era they were in, the kind of design trends that effected them, ecological principles they considered and as a consequence; kind of living spaces they created. The study is done according to combined strategies using case study and logical argumentation research methods together.
\end{abstract}

Keywords: Space Design Strategy, Ecovillage, Alternative Community, Sustainable Living, Drop City, Sieben Linden Ecovillage

\section{ALTERNATIF TOPLULUKLARIN MEKAN YARATMA STRATEJILLERİ: DROP CITY VE SIEBEN LINDEN EKOKÖYÜ KARŞILAŞTIRMASI}

\section{$\ddot{\mathbf{O Z Z}}$}

Birleşmiş Milletler (BM) istatistiklerine göre, dünya nüfusunun \%55'inden fazlası kentsel alanlarda yaşamaktadır. Kentsel alanlar, küresel ısınmanın ve iklim krizinin artmasının ana nedenlerinden biridir. Krizin etkisini azaltabilmek için sürdürülebilir yaşam alanlarının oluşturulması gerekmektedir. Ortak yaşamı destekleyen alternatif topluluklar ise bunlara bir örnek olabilmektedir. $\mathrm{Bu}$ araştırmada, "alternatif yaşam alanları" üzerinden sorgulama yapılarak insanın mekanı yaratma stratejilerinin 
belirlenmesi amaçlanmaktadır. Çalışmanın özünü ve özgünlüğünü oluşturan bu stratejiler, toplumun düşünce ve yaşam tarzından, yaşam alanının bulunduğu ortamın olanaklarına uzanan bir çerçevede ele alınmaktadır. Çalışma kapsamında 60'lı yılların ilk alternatif topluluklarından Drop City ve 90'lı yıllarda devam eden bir eko-köy olan Sieben Lieden Ekoköyü örnekleri incelenmiştir. Çalışma metodolojik olarak birleşik stratejiler kullanılarak vaka çalışması ve mantıksal argüman araştırma yöntemlerini birleştirmektedir.

Anahtar kelimeler: Mekan Tasartm Stratejileri, Ekoköy, Alternatif Topluluk, Sürdürülebilir Yaşam, Drop City, Sieben Linden Ecovillage

\section{INTRODUCTION}

The commune life; creating a life other than the conventional system of living and thinking outside of the box in the modern world was seen in the 60's. This concept grew so popular that "Flower Power" or "Hippie Generation" became known worldwide. The era lasted a little while and ended in the mid70's; nevertheless, the unplugging from the network repeated itself around the 90's in a non-identical way. This study is about exploring the space creating strategies used in alternative communities by comparing two villages from different periods in organizational and spatial aspect.

In the 60 's, architects have foreseen the upcoming need for humankind to design an all-embracing ecology of his own if he is to survive; accelerating population growth, interference with and mastery over the natural, will force him to accept responsibility for every phenomenon on the surface of the earth (Chermayeff \& Alexander, 1966). The responsibility to unite with nature in a sustainable living environment was seen by the people seeking alternative spaces to live together.

According to Frederick Kiesler, a student of Adolf Loos, modern architecture takes place through the creation of new living possibilities and the necessities that will reconfigure society through them (Kiesler, 1991). In this context, examining the "space creation strategies" that are effective in the realization of alternative living spaces created by human communities with different ways of thinking, will shed light on their formation processes. Thus, alternative living areas are created; why and what kind of thoughts and what kind of strategies were followed up and created?

In this study the aim is to create a method-path for the organization of eco-villages and design of their spaces to be established in the future. The research has been focused on a study of behavioral models of two communities; their atmosphere, meaning of everyday life and how they shape their environment. In order to examine this in depth, the research consists of a structure seen through 4 successive steps in Diagram 1.

Research Article - This article was checked by iThenticate 


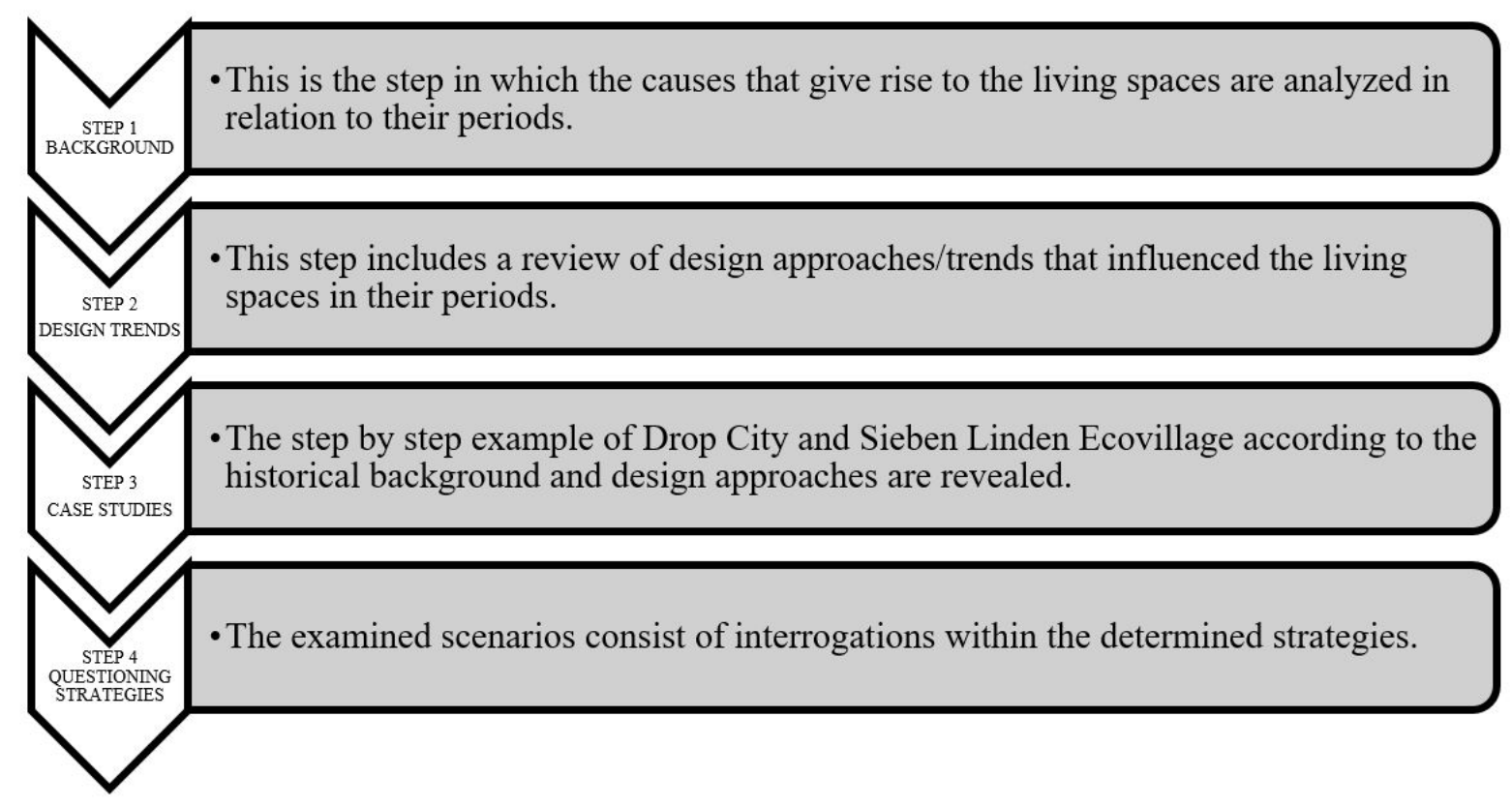

Diagram 1. Structure of the research

The questioning strategies consist of organizational and spatial strategies. The organizational strategies are defined by ecology, economy, society and consciousness according to Litfin's classifications (2014) The spatial strategies are defined by context, form, material, construction technique, interior space, sustainability and design trends.

The questions leading to the strategies that make up living spaces of alternative communities are as follows:

- Do the political and economic events of the decades have an effect on the alternative life?

- How does the design styles of the decade shape the living spaces of alternative communities?

- How did the environmental crisis effect the alternative communities?

- What kind of living spaces were built in the two case studies and what are their differences?

Ecovillages are examined by studying the literature in the scope of the definition (Gilman \& Gilman, 1991), the organization and social life of these spaces. The villages are examined in four perspectives as; ecology, economy, society and consciousness (Litfin, 2014). This vision is used in this study to compare the two cases. There are also studies on different kinds of ecovillages such as an urban ecovillage. One of these studies is about how to revitalize urban neighborhoods by organizing small eco-villages (Sizemore, 2004). There are references about how to grow ecovillages and develop them successfully (Christian, D. 2003; Barton 2003). Christian's study includes basic rules for creating successful communities which is to have a vision, have knowledge, have decision making processes, put agreements in writing, and have conflict resolution methods.

60 's communal experiments were investigated also as a reaction to the global environmental crisis and the need for changing lifestyles. The communes which started out as a hippie commune, spiritual commune or service-oriented settlements evolved as ecovillages towards the 90's. Although there are studies about eco-village housing; their design, materials, positive aspects or shortcomings; they have not been linked to their era or the design styles of the decade they were in.

This study is interested in how the different decades; the social acts, the design movements, shaped the living spaces of alternative communities. In order to make this connection, references from the life in the 60's (Gordon, 2008), design styles of the 60's (Fiell,C, 2000), radical environments from the 60's 
were used. Also, the social and political happenings of the 90's, the design movements like minimalism and green movement were investigated (Anonymous, 1999; Fiell, C. \& Fiell, P., 2002; Herzog, 1996).

\section{BACKGROUND}

In order to examine the subject, we must know the general definitions and concepts related to 60 's communal living and 90's ecological living. The definition of 'commune' is described as; "a group of families or single people who live and work together sharing possessions and responsibilities" (URL-1, 2020). This definition is rather wide because there are reasons for getting together to form a commune. The general properties of a commune are; a sense of common purpose and separation from dominant society; a voluntary suppression of individual choice in favor of the good life of the group; using common buildings; personal interaction and economic sharing (Millor,1999). This being said, it is very difficult to generalize spiritual communes, psychadelic communes, group marriage communes or interracial communes with a massive increase throughout 1960 to 1975.

As the communes decreased towards the 80 's, new kinds of intentional communities emerged. A growing number of people were interested in establishing ecovillages. Ecovillage is a sustainable human settlement which is in harmony with all aspects of life, including the cultural, ecological and spiritual dimensions. An ecovillage is most frequently defined in the following way: a human-scale settlement that is intended to be full-featured - providing food, manufacturing, leisure, social opportunities, and commerce - the goal of which is the harmless integration of human activities into the environment in a way that supports healthy human development in physical, emotional, mental, and spiritual ways, and is able to continue into the indefinite future (Bang, 2005). Examples for the ecovillages can be found globally like the Auroville, Crystal Waters, Findhorn, etc. These examples all have different economic and social structures, different beliefs and world views and different understanding of being ecological. Some of them are together for sustainability, communal living for ecological reasons. Some of them come together for spiritual beliefs; some for organizing affordable shelter and food for poor communities and some are tired of individualistic societies so they want to be in contact with their neighbours. The ecovillagers are sharers; they share the land, food, living spaces, cars and tools. So, the footprint of each individual is less than the average of their country. Ross Jackson (2004), stated that "the ideal ecovillage does not exist. It is a work in process - a fundamental component of the new paradigm, where much is yet to be learned."

The era in which these communities are formed is very important so as to understand better the reasons for searching alternative living; the structure of their organization and the spatial outcome of living spaces.

\subsection{0's}

In the 1960 's, there was a widespread social act happening all throughout the decade. People wanted to change the way they live and no matter what they believed in; they came together to build an alternative world for themselves.

The young population had increased because of the baby-boom after the 2nd World War. There was a dynamic, creative youth versus the old generation that disapproved their way of living. So, these youngsters came together; bonded by thoughts of living joyous, artful, peaceful and in harmony with nature to form a community that rejects the materialistic way of life and consumerism. There were a few subjects that encouraged them to do so.

The ongoing Vietnam War caused a reaction among the youth to search for better ways to live in peace. The demand of equal rights caused more than 200,000 people came together in 1963 to listen to Martin Luther King's speech in Washington. There were student riots happening around 1968. The supporters of anti-nuclear movement marched together in the streets of cities like London (Yapp, 2005). Freedom spirit could be sensed in all aspects of life; in music, in fashion, in commercials and everyday life. Young population wanted to move away from the standard ideal family of the post war The youngsters now wanted to embrace their differences and live a joyous life. So, the counterculture of 60's; outlaws, gays, women, African Americans, people who believed in peace after the Vietnam War, people who believed 
in group marriage, people who were searching for what to believe in; got together to form their own communes.

Different groups, they call tribes, left the city one by one because it was a time to simplify to go back to Mother Earth. Some examples of these communes are; Sheep Ridge Ranch, Olompali Ranch, The Hippie Tribe, The Hog Farm, Drop City, Libre and The Milbrook Trip. There were political and revolutionary communes like Black Communalism, Trans-Love Energies, Gay Collectives, Iowa City Women's Collective. Also there existed Mystical, Yoga or Christian communes like LAMA Foundation, Oregon Family, Ananda Cooperative and Sri Ram Ashrama. Apart from these groups, there were group marriage communities and service communities such as Camphill Village, Catholic Worker Farm, Synanon and Gould Farm.

\subsubsection{0's Design Trends For Living Environment}

In the 1960's, Vernacular Architecture was trending as much as Late Modernist designs. If we consider their living spaces, people were tired and bored of the monolithic blocks they lived in after the $2^{\text {nd }}$ World War and the perpendicular lines of modernist movement. Architects and designers were also discussing the effects of nature in our lives and how our living environment will be in the future if the developing cities grow more and more. The need to build an organic bond with nature and environment came into agenda. The idea was that, real pleasure of nature cannot be enjoyed except through unhurried contact and our lives, and especially the life processes of families, are stimulated by the visible order of nature.

\section{"All these demands dwellings close to the ground with easy access to outdoors, an organic whole in which indoors and outdoors are integrated in a single comprehensive shelter." (Chermayeff \& Alexander, 1966).}

The movements related to architecture and design can mostly be seen in two groups as the rational and the irrational in these years. The rational movement was effected by technology and the revolution in communication, possibilities of hard and soft synthetic materials and developing shaping techniques. (Tuncel, 2007).

As opposed to this late modernist movement, the radical design of the spirit of 60's counterculture continued into the early 1970's and became even more extreme. Identified with organic forms in the Pop era, most plastic materials, colorful, toy like designs; cynical, provocative designs reminiscent of popular subjects of the period (Özçam, 2013). The youth culture of the 60's represented a revolt against traditional behavior patterns, while pop art represented a rebellion against aesthetic norms. The banal objects of daily life, comics and ads stood as art and as a parody of consumer society. Modular "space age" environments were created using state-of-the-art objects with injection moulded plastics. The Radical Design groups were making projections for the future as new utopian projects. New ways of living were discussed in those years when there was much hope for the world who had gone all the way to the moon (Tuncel, 2007).

In the 70's one of the fundamental themes of modernism was waste utilization. In 1974, the "Des-in" group was turning tea boxes to cabinets, old tires into couches. Other designers were processing ropes, cardboard boxes, used paper by special techniques and reuse them as new objects. Another movement was the Do-It-Yourself concept. The main idea was to build, restore or renovate something without getting help from a professional.

In the interiors, the sense of a primitive shelter and a shared space influenced people. Interiors had disorienting illusions using mirrors, converging panels. Floors had mounds and valleys of thick carpets that enabled people to engage with one another freely. That was the style for seating also. Contoured seating was seen mostly beneath floor level in conversation pits and sunken living rooms. There was a widespread fascination with 'microenvironments', rooms within rooms, and cocoonlike chambers that felt like the womb. These environments were influenced by the successful space voyages and humankind landing on the moon. All of these design movements affected the spaces created by the alternative communities.

Research Article - This article was checked by iThenticate 


\subsubsection{Case Study 1: 60's Radical Community "DROP CITY"}

Drop City was the first rural communal group founded in 1965 by Gene Bernofsky, JoAnn Bernofsky, Richard Kallweit and Clark Richert. At the University of Colorado, these four students, who studied art and cinema, started out with 6 acres of land in Trinidad, and at the same time, they stamped the turning point with the aim of creating a life unit outside community structure.

Drop City residents consist of writers, architects, filmmakers, magicians, musicians. This communal group was first impressed by the work of Allen Kaprow, who featured in multimedia events in New York. Along with this, they were performing the art they call Drop Art in this group they have created. These people, who defined themselves as artists, regarded Drop City as an end product of this art. John Curl, one of the group of believers in Drop city, expressed their philosophy in the following way: "Drop City thinks that the big leap in communion human consciousness will be due to the reshaping of the planet." It is believed that old attitudes and thoughts can be removed, as the past can be completely erased. There is the idea that everyone is free, everything is based on pleasure and pleasure is based on no pressure, only based on the natural fulfillment of the internal necessities and demands in a naturally simple way. Because in Drop City the main idea is "nothing." The group, which continued until 1973, has had the participation of twelve adults and children until 1968. In those years, this group was taken as an example by many organizations with similar ideas.

The members of the commune who slept in their cars in the beginning for shelter, later set up tents and began to build simple types of shelters. Clark Richert said they did not know how to build a shelter when they first arrived (URL-2, 2020). The dome-shaped geodesic shelters that they later made provided protection and gave Drop City an identity. Thus, Drop City has become a symbol that multiplies a cultural dimension against the existing culture. Communities similar to Drop City have been created, and people's lives have become widespread in the thought of living like "art". This life model was actually an experimental field. When viewed in this way, "Drop City is neither a dream nor a magazine fallen from the sky." According to Clark Richert, "Drop City is a great endeavor and a lot of experimentation for three years." (URL-2, 2020).

Inside the domes were their works of art forming the interior walls. Geodesic domes were used also because "have the highest proportion space in interior to exterior, and so have the minimum levels for heat loss, and in structures all structural parts evenly spread forces" (Ghorbanzadeh, 2016). The constructed shelters were designed with a conceptualization of the molecular structure of Buckminster Fuller. But due to Fuller's inability to fully apply the method, the first dome was made up of twenty pentagonal surfaces, not being in a geodesic form. Because of the lack of a material source, the shelters built were constructed of materials taken from the garbage.

The first shelter was made of double and quadruple plywood plaques combined and covered with wires. Impregnated aluminum paint is applied to the coated surfaces. Thus, the leakage is prevented. The windows are made of waste of old cars. The first shelter thus built resembles a spacecraft. The second shelter built is the "Icosadome", which is built for the common kitchen, which is about six meters in diameter. The structure is formed by joining three-inch rods, coating the plywood with plywood, and then applying pitch to the plywood for sealing. After these two construction experiences, the group members wanted to try to make more ambitious shelters. The Theater Dome, twelve feet in diameter, is the second largest shelter in Drop City. The Theater dome, however, is the first space designed for activities that resemble the geodesic dome most. The structure is made up of the combination of double and quadruple parts with metal elements. The outer cover of the structure is the parts obtained by processing the upper roofs of the old cars.

\subsection{0's}

After the age of communes of the 60's was over, the era of consumerism started as the 80 's came. The first years of the 80's saw the rise of capitalist world where the media supported consumption in every way and so extravagant lifestyles could be seen. Towards the end of the 80 's, the optimism in the atmosphere decreased related to economic, social and environmental problems. The outcome of over- 
spending and consumerism led to dissatisfaction, pollution and a lifestyle where the images were more important than content. In the 90's alternative voices were heard like Naomi Klein's "No Logo" book or Mark Dery's "Culture Jamming" or a day organized against consumption, "Buy Nothing Day".

After the environmental disasters in the late 80 s, the wars that took place in the beginning of the new decade continued this atmosphere. In 1991, the USSR broke up and the communist regime collapsed. In 1992, while the end of the Cold War was officially announced, Bill Clinton period started in America. Meanwhile, the most important developments of the 1990s were experienced in bio-technologies and information/communication technologies like the world wide web.

While these were the negative and positive aspects of life in the 90 's, the concern for the environment continued. In 1983 the UN General Assembly realized that there was a heavy deterioration of the human environment and natural resources. So, they organized a commision to rally countries to work and pursue sustainable development together. The Brundtland Commision released a report with the title "Our Common Future" there is a definition of sustainability. It is defined as the process of meeting the needs of the present day without sacrificing the possibilities of future generations to meet their own needs (Gönel, 2007). In 1987, Gaia Trust was founded in order to support sustainable living; furthermore in 1995 GEN (Global Ecovillage Network) brought together the communities aiming for a sustainable future.

\subsubsection{0's Design Trends For Living Environment}

The 90's witnessed the awareness in ecological matters emerging. This was when the music changed from glamour groups to grunge alternatives and post-modernist designs gave way to minimalist approach. Lightness, subtlety, pure forms, new materials with composite structure, objects and spaces colored by changing of light; reflect the minimal understanding that emerged in this decade.

Organic design is actually a trend that has existed in the history of design, but it has become really popular in the 90 's. It is also defined as biomorphism or user-friendly design in industrial design. Organic forms designed before were evaluated as fantastic or seriously expensive works because the production of complex geometric shapes was very difficult. The new CAD/CAM technologies offered designing and shaping possibilities that did not differ in terms of cost or convenience between mass production of shapes in natural forms.

To summarize the design trends of the 1990s, it is enough to look at the Expo 2000 Fair in Hannover. The main topic of the fair, which was titled "Human, Nature, Technology: A New World is Born', was sustainability. It was seen that some of the exhibition buildings were completely recyclable or detachable. The Japanese Pavilion, which uses cardboard pipes as load bearing structure, was recovered at the end of the Expo and turned into products such as pens and notebooks. At the same time, the spaces including the concepts of permeability and lightness have been a feature that the buildings in the fair tried to obtain. (Anonymous, 2000)

In the information/communication age, there are smart materials, even ecological plastics. These materials include composite materials that are light, strong, formable at the same time; heating systems that take the inner heat of the ground to the house, lighting systems that use very little energy, smart systems that turn on and off the ventilation, lights, electrical equipment. Even without such technologies; we are more experienced to use the knowledge of permaculture, live together under some rules to make the eco-living possible. The most important difference is the way of thinking.

When we look at ecology in terms of technology, it is seen that human and environment are effective in interaction and on each other. In this case, natural changes are required for the continuity of natural life and technological changes are needed for the harmony between human and environment. Although it is acknowledged by many people that ecology has been destroyed by technology, it is an undeniable fact that technology has provided many improvements in protecting the ecological balance. The concept ecotech, which consists of the word's ecology and technology, refers to the maximum protection of ecology by technological means. Eco-tech natural elements are a paradigm that explains the nature of ecology

Research Article - This article was checked by iThenticate 
and technology in sustainable planning based on natural processes, protection of nature and utilization of technology in this protection (Ercoşkun, 2007).

\subsubsection{Case Study 2: 90's Ecological Community "SIEBEN LINDEN ECOVILLAGE"}

The Ökodorf Sieben Linden idea emerged in 1989 with the concept of an eco-village as a project. A group of people came together to research about how to handle the land that was found and bought in 1997 (URL-3, 2020). The aim of this ecological village project was to create a modal that will balance economy and ecology; the rural and urban cultures while being a modal for the future of living. This modal reflects that people may have more responsibility towards nature. So, it shows that people can effect diversity and quality of the environment in a positive way without destroying the nature. This "socio-ecological settlement modal" that is realized is the agricultural areas, forests and living areas near Poppau village in Germany. Ökodorf Sieben Linden was constructed according to four criteria of Global Ecovillage Network (GEN). These are; ecological data, social data, economic data and world view. Although all of these are of the same importance, Ökodorf Sieben Linden focuses on ecological and social values. The project is also a "learning area" for everyone.

The people of Ökodorf Sieben Linden consist of 40 children and 100 adults. The idea of living communally is accepted in the village. This makes Ökodorf Sieben Linden a place where people who share space but have different ideals living together. The village consists of public spaces built on a main line, guesthouses, semi-public spaces surrounding public spaces, and spaces inhabited by village residents on the outskirts. This spatial organization is designed to provide neighborhood relations and to prevent noise. Therefore, it is not allowed to drive in the village to avoid noise. The venue used as a farmhouse in Ökodorf Sieben Linden was transformed into a central building with a seminar center, kitchen, library and infrastructure system. Other buildings include an organic food store, a jewelry store, several offices, guest rooms and a bar.

The first ecological structure is two low-energy houses established in 2001. After these two buildings, the houses were built with local materials such as straw bales, wood and soil. Straw house projects in Europe were first built in Ökodorf Sieben Linden. In this way, an experimental modal is tried by combining straw bales with different properties with different methods. However, some are trying to build new homes using second-hand housing components with local and recycled materials. Building a building in Ökodorf Sieben Linden is not an individual work, but an act of collective action. In this way, the principle of living in a community is supported.

Research Article - This article was checked by iThenticate 


\section{QUESTIONING STRATEGIES}

In this part of the study, two alternative living communities; their backgrounds, their visions and their built environments are compared: Drop City commune and Sieben Linden eco-village.

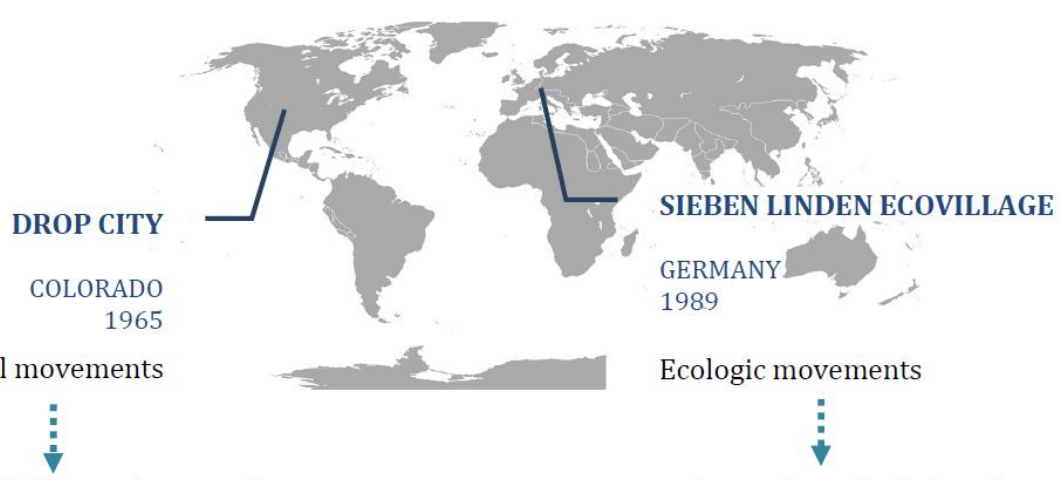

- It is an artistic experiment environment.

- It is a socio-ecological settlement model.

- Based on artistic basis.

- Based on ecological basis. The goal is to provide a

- The goal is that all internal requirements and wishes are fulfilled in a natural simple way without pressure, where everyone is free and everything is based on joy and balance between economy, ecology, daily events, rural and urban culture and to create a model for future life. pleasure.

- They lived in Geodesic domes made of waste materials.

- They live in houses made of straw bales.

- They have financial resources.

- They have no financial resources.

- There is collective labor type assistance.

- They did not live according to ecological principles, only used passive solar.

- They did not have technological elements.

- There is collective labor type assistance.

- They live according to ecological principles.

- Technological elements (such as the use of photovoltaic batteries).

\section{Diagram 2. Analysis of Alternative Living Modals}

The strategies, which are indicative of the essence and authenticity of the research, may lead to a way of thinking about the decisive role of space creation in human life. Strategies that make up the methodology can be explained as follows:

\subsection{Organizational Strategy}

Organizational strategy is the strategy in which the alternative society that constitutes the living area has a kind of organizational structure, community structure, world view, purpose and lifestyle. In order to examine this strategy used in both communes, we have analyzed it in four branches as ecology, economy, society and consciousness according to Karen Litfin's classifications which is structured mainly on Gaia Education programmes of their Ecovillage Design curriculum.

Research Article - This article was checked by iThenticate Copyright $($ C The Turkish Online Journal of Design, Art and Communication 
Table 1: Organizational strategies of Drop City and Ökodorf Sieben Linden Ecovillage

\begin{tabular}{|c|c|c|}
\hline & Drop City & Ökodorf Sieben Linden Ecovillage \\
\hline$\frac{8}{8}$ & $\begin{array}{l}\text { Recycling, using minimum resources; } \\
\text { passive solar houses, using the sun as } \\
\text { energy source. }\end{array}$ & $\begin{array}{l}\text { Permaculture, biodiversity, using local materials; } \\
\text { using the sun as energy source }\end{array}$ \\
\hline & $\begin{array}{l}\text { They bought } 6 \text { acres of land for } 450 \$ \text {. } \\
\text { They have no income. The materials for } \\
\text { domes are taken from junkyards, } \\
\text { salvaged car parks. }\end{array}$ & $\begin{array}{l}\text { They own their land. Everyone has an outside job.. } \\
\text { They have projects funded by the German Federal } \\
\text { Environment Agency and GEN also. Every resident } \\
\text { finances with their individual share of nearly } 13,000 \\
\text { Euro. They have legal and equal footing. }\end{array}$ \\
\hline & $\begin{array}{l}\text { Society is composed of artists. They } \\
\text { reject community structure. They have } \\
\text { common areas like kitchen. }\end{array}$ & $\begin{array}{l}\text { This is a learning area for everyone. Education is } \\
\text { important. They have } 5 \text { neighborhoods and a } \\
\text { common kitchen. They have a meeting once a week. }\end{array}$ \\
\hline 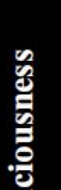 & $\begin{array}{l}\text { Belief in pleasure, art, reshaping of the } \\
\text { planet, anti-establishment, and } \\
\text { experimental rebellion. }\end{array}$ & $\begin{array}{l}\text { The goal is to create a new culture; a modal that will } \\
\text { balance economy and ecology while being } \\
\text { responsible towards nature. Contact is important. } \\
\text { Focuses on ecological and social values. }\end{array}$ \\
\hline
\end{tabular}

Accordingly in Table 1, organizational strategies were analyzed over Drop City and Ökodorf Sieben Linden samples. We can see from this table that the main reason of composing an ecovillage is the sustainability aspect for Sieben Linden. This ecovillage has given more thought on economy and the legal arrangements of the land, so the society can live peacefully and prosper together with smaller footprint. Whereas in Drop City, the excitement of creating an off-grid settlement full of artists and experimentation is much more important than ecological point of view.

\subsection{Spatial Strategy}

Spatial data (function, context, form, material, construction technique, etc.) specific to the settlement were evaluated within the scope of forming strategy. It is the strategy that specifies the data about how the interior and exterior spaces were used and how spaces were organized. Drop City and Ökodorf Sieben Linden Ecovillage's analysis of space strategies are as seen in Table 2.

Research Article - This article was checked by iThenticate Copyright $(C)$ The Turkish Online Journal of Design, Art and Communication 
Table 2: Spatial strategies of Drop City and Sieben Linden Ecovillage

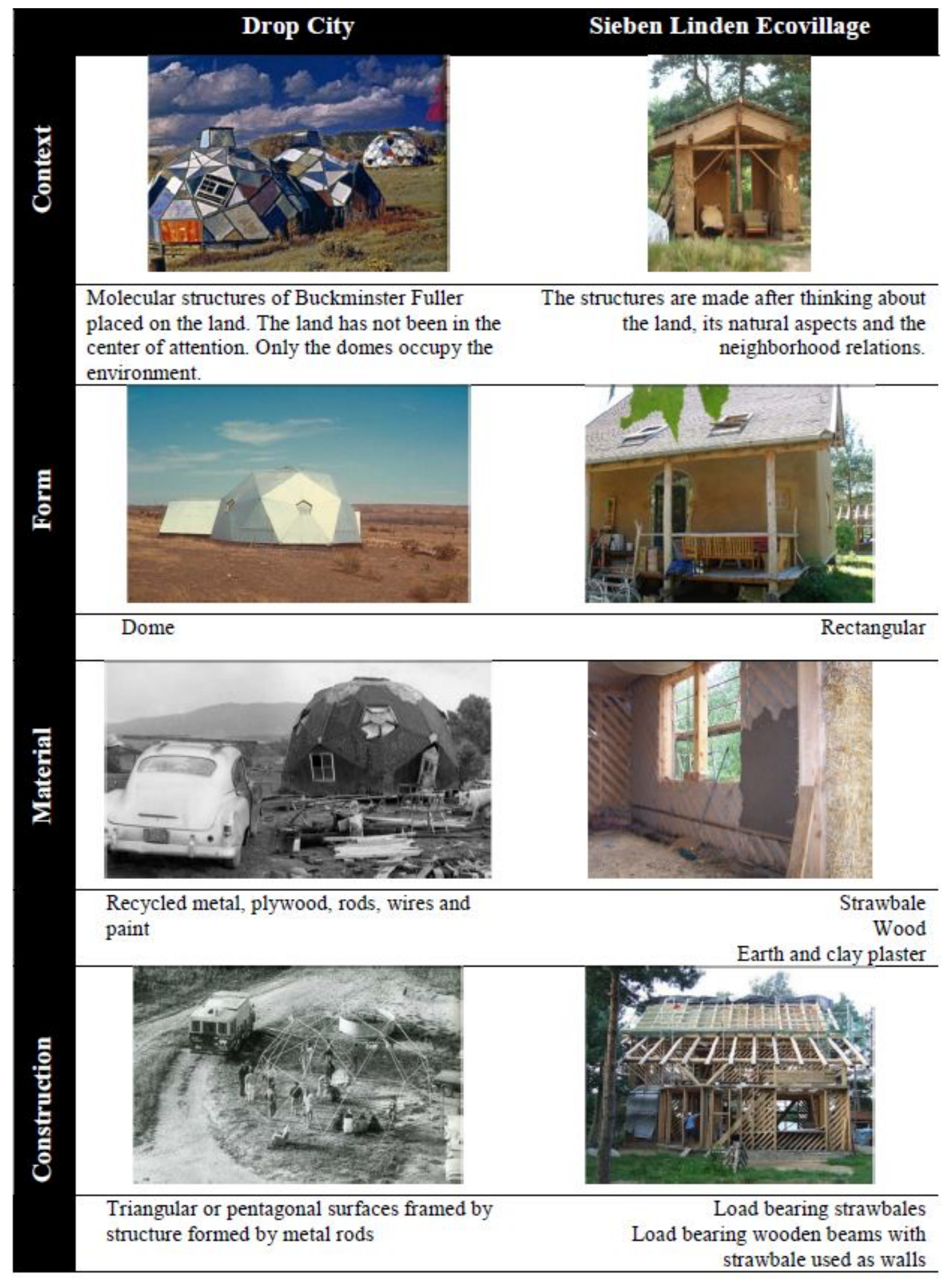

Research Article - This article was checked by iThenticate Copyright (C) The Turkish Online Journal of Design, Art and Communication 


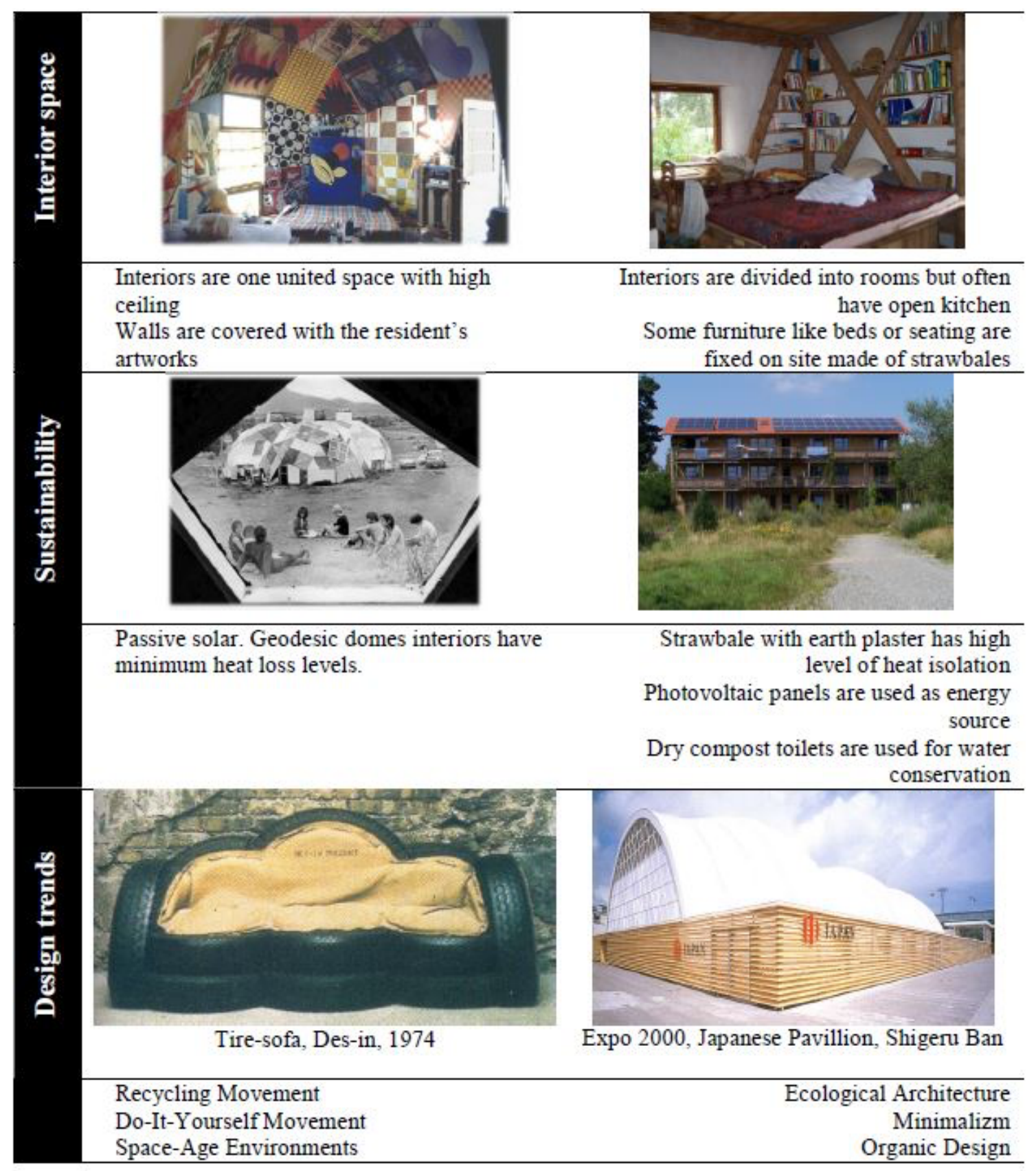

\section{CONCLUSION}

As a result, in this study, two different alternative communities' examples belonging to different times were examined. Drop City was a pioneer among the attempts to live out of the boundaries of mainstream life. It had a reaction towards consumerism and living individually. This experimental co-living influenced many other counter communities. The difference of Drop City was their attempt to live their lives as a work of art. While doing this they were re-thinking architecture by making structurally efficient and recycled domes. They were affected by the design movements going on in the decade; especially radical design.

On the other hand, 30 years later in Sieben Linden, living together had many other meanings. The aim was mostly ecological. They were thinking architecture as using sustainable local materials. It was not only about buildings but to use the land efficiently by permaculture principles while encouraging

Research Article - This article was checked by iThenticate

Copyright (C) The Turkish Online Journal of Design, Art and Communication 
biodiversity in the area. This co-living attempt was much more systematic and organized. They were also affected by the design movements of the decade; mostly ecological and sustainable design.

There were a lot of reasons why most of the collectives of the 60's didn't survive until today. First and the most important was the lack of organization. Secondly, the people in the communes made it difficult to live together. There were people who didn't contribute and didn't work. Also, because there were no rules about getting in the communes; lots of people with psychological problems and thieves; people who escaped from military came to Drop City because the commune was famous for its artistic lifestyle and extraordinary buildings that Buckminster Fuller made famous by giving them an award for best dome structure. Thirdly; because there were complaints from the neighbours, the laws got stricter about building codes and occupancy limits. Later the first occupants left and by 1973 the commune was deserted.

There is no one perfect model of an ecovillage. Sieben Linden still survives due to the fact that the four main principles of ecovillages are considered in their structure. Firstly, ecological principles including using the sun as the energy source; using water consciously by using compost toilets, making an artificial lake to filter the water; thinking about biodiversity, and limiting waste production. Secondly, economy is thought about and they create ways to make money from education. Also, most residents have jobs outside of the village. Thirdly, the societal structure and bonding is very important in Sieben Linden. Also, they invite their neighbors to their community and cooperate with them. The fourth criteria which is consciousness and the world view does not stand on beliefs of freedom only. As a result, we can say that social sustainability is the backbone of ecological sustainability.

From this point of view, it is understood that architecture and design approaches are not only realized by certain rules, but are also related to people's lifestyle, ideologies, and their problems due to their perspective on events. It is thought that such alternative living spaces will be effective in the development of architectural practice, the emergence of new approaches and the expansion of architectural culture and thought.

In the light of this study, we have the means of looking into the future of alternative living modals, their spaces and characters. By following the steps discussed previously; investigating the background with economic, political, environmental and technological factors should be considered. After that, the design trends of the time should be examined.

From 2021, we can say that the crucial point will be climate crisis and from this point more people will shift their lives looking for alternative living areas. With the wireless technologies, working online will increase creating a freedom of living areas which will increase a demand for ecovillages. The natural habitat is in need of conservation due to the crisis; therefore, we can foresee new materials designed that are environmentally friendly used in architecture. The spaces also will be produced by the future technologies of 3D printing and the need for sustainable clean energy will increase. So, in conclusion, the spaces created by alternative communities may embrace eco-tech designs in the future, bringing nature and technology together. Taking the positive aspects of the two studied communities; the organizational structure and ecological approach of Sieben Linden with the creative materials and forms of Drop City united by new technologies should be considered as the new alternative living modal.

\section{REFERENCES}

Anon. (1999). AD Aspects of Minimal Architecture II. Academy Press; 1st edition.

Anon. (2000). Domus Magazine. no:6, August-September.

Bang, J.M. (2005). Ecovillages: A Practical Guide to Sustainable Communities. New Society Publishers.

Barton, Hugh eds. (2000). Sustainable Communities: The Potential for Eco-neighborhoods. London: Earthscan.

Chermayeff S., and Alexander C. (1966). Community and Privacy. Penguin Books, Middlesex, England. 
Christian, D. (2003). Creating Life Together: Practical Tools to Grow Ecovillages and Intentional Communities. New Society Publishers, Canada

Ercoşkun, Ö. (2007). "Sürdürülebilir Kent İçin Ekolojik Teknolojik Tasarım Ankara Güdül Örneği”, PhD diss., Gazi Üniversitesi.

Fiell, C. \& Fiell P. (1999). Design of the $20^{\text {th }}$ Century. Taschen, Köln.

Fiell, C. \& Fiell P. (2000). 70's Decorative Arts. Taschen, Köln.

Ghorbanzadeh M. (2016). How to Build a Geodesic Dome An Overview and Introduction for Construction of Geodesic Domes in a Simple Word in Addition With Studding a Case and Designing a Research Center with this Structure. Special Issue of Curr World Environ;11

Gilman, R. and Gilman, D. (1991). Ecovillages and Sustainable Communities: A Report for Gaia Trust. Gaia Trust seminar in Thy, Denmark.

Gordon, A. (2008). Spaced Out Radical Environments Of The Psychedelic Sixties. Rizzoli International Publication, USA.

Gönel F. D., (2007). Ekolojik Ayakizi. Yıldız Teknik Üniversitesi Basım-Yayın Merkezi, İstanbul.

Jackson, R. (2004). “The Ecovillage Movement”. Permaculture Magazine 40, 25-30.

Kiesler, F. (1991). Mekan Kenti Mimarlığı. U.Conrads içinde, 20.yy Mimarisinde Program ve Manifestolar, Şevki Vanlı Mimarlık Vakfi, İstanbul.

Litfin, K.T. (2014). Eko Köyler translated by Pinar Ercan. ALFA, İstanbul.

Lucie-Smith, E. (1979). Furniture A Concise History. Thames \& Hudson, London.

Millor, T. (1999). The 60's Communes: Hippies and Beyond. Syracause University Press, New York.

Özçam, I. (2013). "Biçim Dili ile İletişim Ekseninde Mobilyanın Sembolleşmesi ve Günümüz Mobilyasının Sembolleşmesinde Rol Oynayan Sosyolojik ve Teknolojik Etkenler" PhD diss. M.S.G.S.Ü. Science Inst.

Sizemore, S. (2004). Urban Eco-villages as an Alternative Model to Revitalizing Urban Neighborhoods: The Eco-village Approach of the Seminary Square/ Price Hill Eco-village of Cincinnati. Ohio, Master Of Community Planning, University of Cincinnati.

Tuncel, D. (2007). Factors Effecting Interior Space Aesthetics in the 70's, International Congress of Aesthetics. Ankara

Yapp, N. (2005). Getty Images 1960’lar translated by Canan Feyyat. Literatür Yayınları.

\section{WEB REFERENCES}

URL-1 https://dictionary.cambridge.org/dictionary/english/commune (Erişim Tarihi: 05.08.2020)

URL-2 http://www.clarkrichert.com/drop-city (Erişim Tarihi: 18.10.2020)

URL-3 https://siebenlinden.org/en/ecovillage-2/sieben-linden/ (Erişim Tarihi: 20.12.2020) 